\title{
AGROECOSYSTEMS OF LAND SUITABILITY IN SUB-DISTRICT OF SOUTH KUTA FOR COMMODITY DEVELOPMENT HORTIKULTURA FRUITS IN BADUNG DISTRICT, BALI
}

\author{
Ni Made Trigunasih* and I Nyoman Dibia \\ Study Program of Agroecotechnology, Faculty of Agriculture, Udayana University, Bali \\ *Corresponding Author: trigunasih@unud.ac.id
}

\begin{abstract}
This study aims to: (1) to know the suitability of the land for the development of several fruit horticultural commodities in the Sub-district of South Kuta, (2) determine the suitability of land in agroecosystem and its limiting factors, (3) provide ecommendations for land management in the study area. The study used a field survey method with the determination of observation samples carried out in a stratified purposive sampling with land units as the strata. Land quality/characteristics as a determinant of land suitability observed include: annual mean temperature, water availability; rooting media; availability of oxygen; nutrient retention, $\mathrm{CEC}, \mathrm{BS}, \mathrm{pH}$, and organic matter; nutrients available; erosion; flood hazard; land preparation. Land suitability assessment is done by matching the land quality with the growing requirements for the plants evaluated. The results showed that the actual land suitability for food crops of fruit horticulture (citrus, mango, starfruit, banana, sapodilla, grape, klengkeng, papaya, grain guava, guava, jackfruit, soursop, avocado, srikaya, breadfruit and pineapple) belonged according to conditional marginal suitable (S3), until not appropriate (N) with the quality of the land as a limiting factor are: rooting media (effective depth of soil); land preparation (surface rocks and rock outcrops); erosion hazard; and nutrient availability (especially $\mathrm{N}$-total and P-available). The assumption is that some land quality/characteristics that are as limiting factors can be improved, then the suitability of the potential land is quite suitable (S2) to marginal suitable (S3) with the quality/characteristics of the land as a limiting are: availability of water (long dry months), rooting media (effective depth), land preparation (surface rocks, rock outcrops), and nutrient retention (rather high soil $\mathrm{pH}$ ). Increased land productivity in the study area can be done by improving land management by providing inputs such as: the addition of sufficient organic material, adition of fertilizer containing elements of $\mathrm{N}$ (ZA), and fertilizer containing elements of Potasium (SP36), taking conservation measures in the form of making terraces on sloping lands.
\end{abstract}

Keywords: Land Suitability Evaluation, Land quality/characteristics, Horticultural and fruit commodities, South Kuta

\section{INTRODUCTION}

The dynamics of development in Badung Regency have shown a lot of rapid progress. This can be seen from the relatively stable economic growth which is supported by a conducive investment climate and political stability and security that are maintained, causing the development of the tourism sector as the economic locomotive of Badung Regency to continue to this day. But on the other hand the rapid development of economy and tourism has led to an increase 
in land requirements that are quite high, thus impacting the number of changes in space use patterns.

Conversion of land use in an area that is carried out without considering ecological/sustainability aspects, social and cultural aspects, will disrupt the balance of activities in the overall development sectors. Data in 2009 shows that the built area in Badung Regency reached 8,226.20 Ha or $19.66 \%$ of the area of Badung Regency and left $80.34 \%$ of the area that had not been built. Land use conversion analysis carried out using the overley method in 2009 space utilization map with a 2013 space utilization map indicates an increase in built land of \pm $538.08 \mathrm{Ha}$ or an increase of $6.54 \%$ from 8,226.20 Ha in 2009 to 8,764.28 Ha in 2013. So that the percentage of space utilization in 2013 for built land is 20.94\%; and the remaining open land is $79.06 \%$ (BPS Badug Regency 2015).

Based on the distribution of the conversion of open land to built-up land, it seems that a large area of land conversion has occurred in 3 (three) districts, namely South Kuta District covering $\pm 216.95 \mathrm{Ha}, \pm$ North Kuta District \pm 138.85 and Mengwi District covering $\pm 85,45 \mathrm{Ha}$. The general characteristics of the conversion of open land to built land in Badung Regency can be classified as follows: in the sub-district of South Kuta all land conversion from mixed gardens/drylands is transformed into residential and tourist accommodation; Kuta, North Kuta and Mengwi sub-districts convert land from mixed gardens / fields and rice fields to residential and tourist accommodations; Abiansemal and Petang subdistricts conversion of land from mixed gardens / moor and rice fields turns into settlements.

The occurrence of land conversion from agricultural land to non-agricultural because of economic value or economic rent of agricultural land is lower than if used for other uses. This encourages landowners to convert their land or sell it to others.

Reduced open land due to land conversion that is carried out without regard to conservation rules (ecological aspects) leads to enormous long-term social losses. Conversion of agricultural land, especially rice fields will have an impact on decreasing food production capacity, agro-ecosystem degradation, degradation of agricultural traditions and culture, especially the Subak system which has become a world cultural heritage. Therefore, controlling land conversion in Badung Regency is one of the most strategic policy issues and requires strong support from all related elements because of the weight of the challenges faced today. Therefore, the Badung Regency Government continues to strive to reduce the 
occurrence of land conversion, especially agricultural land into non-agriculture.

There are three policy approaches adopted by the Badung District Government in controlling land conversion including political approaches, economic approaches and social psychology approaches. Political or regulatory approach, namely the determination of the Badung Regency Regional Regulation (Perda) No. 26 of 2013 concerning the Badung Regency Spatial Plan for 2013-2033 as a legal aspect for the allocation of space for cultivation and conservation functions. In addition, the Badung Regency RTRW Regional Regulation has included the allocation of Sustainable Agriculture Land (LP2B) to ensure the availability of eternal food land in Badung Regency.

The high rate of conversion of land, especially paddy fields to become nonagricultural land in Badung Regency as mentioned above has an impact on the decline in food production, especially rice/crops. Therefore the paradigm of paddy fields as the backbone of agriculture, namely as the main supplier of food production must be abandoned, and must turn to dry land including marginal/critical dry land.

These lands in Badung Regency, especially in the sub-districts of South Kuta, are still quite extensive and have the potential to be developed into dry land agricultural areas to support tourism.

Based on BPS data from Badung Regency in 2015, the area of upland /mixed gardens in South Kuta Sub-district is $980 \mathrm{Ha}$. The area is a large and potential bishop area but requires intensive management with adequate input and application of technology. Dry land agriculture in the future is expected not only to support food security programs, but also to be a powerful driving force for regional and national economies. However, it should be noted that dry land has agroecosystems that are inherently more fragile, more underdeveloped, and less developed and lack serious attention from the government compared to wetland agroecosystems. Therefore, sustainable dry land management technology is needed in accordance with its biophysical potential. This means that the land management system is not only able to improve the quality or productivity of land and the quality of environmental resources, but also able to improve the welfare of the community and regional economic growth. In order to conduct dry land management properly, a land management technology is needed that is appropriate and on target according to performance (the quality/characteristics of the land resources concerned.

Efforts to obtain the right target technology require a multi-disciplinary 
approach to identify priorities for the development and testing of technologies that are able to answer problems in the comprehensive use of land resources. So in every land use planning, there needs to be an in-depth study to find the right technology to improve productivity, increase farmers' income, preserve the environment, and be accepted by the local community.

So basically in the development of land resource management technology must be able to answer the wishes and problems of farmers, not only the wishes of researchers. Therefore, the activity must be preceded by an evaluation of land suitability and the selection of commodities that have market prospects, and the commodity really matches the region concerned. So it can be concluded that in each land use planning it needs to be supported by an accurate and up-to-date land database as a basis for land suitability assessment for its development purposes.

\section{Research purposes}

1. To know the suitability of the land for the development of several fruit horticultural commodities in the Sudistrict of South Kuta,

2. Determine the quality/characteristics of the land that is as a limiting factors in the development of several fruit horticultural commodities in the Subdistrict of South Kuta.
3. Provide recommendations/direction in land management in the Subdistrict of South Kuta.

\section{MATERIAL AND METHODS}

The research was conducted from March to July 2017 starting from preparation to writing research reports. The study was conducted in the District of South Kuta which is a dry land (mixed garden). Based on the 2015 Badung Regency Central Statistics Agency (BPS), the area of South Kuta research area is $101.17 \mathrm{~km} 2$ and 980 ha is dry land/mix garden.

The study uses land evaluation survey method with observation sampling based on homogeneous land units. The selection of this survey method is based on the purpose of the study, namely to obtain a complete, clear and informative picture about the potential and constraints of the land/land resources of the study area. The quality/characteristics of the land used as a determinant of land suitability include: temperature (annual mean temperature); availability of water (rainfall and dry months); availability of oxygen (soil drainage); rooting media (soil texture, coarse material, and soil depth); nutrient retention (soil CEC, base saturation, $\mathrm{pH}$, and organicC); nutrients available (N-total, P-available, and K-available); toxicity (salinity); erosion hazard (slope, erosion hazard); flood/inundation hazard; land preparation 
(surface rock/stoniners, and rock Landuse outcrops/rockoutcrop).

The research area in general consists

Land suitability analysis for each of mixed gardens/dry land, and settlements. commodity evaluated using criteria from the Dry land area/mixed garden covering 980 Technical Guidelines for Evaluating Land for ha.

Agricultural Commodities (Ritung et al., 2012). The land suitability classification is determined by "matching" between the land quality and the growing requirements (crop requirements) of each crop commodity evaluated. Land suitability is determined at the sub-class level. As the main basis in the selection of the evaluated crop commodities emphasized on commodities that meet the requirements of agroclimate (annual mean temperature, average annual rainfall, and duration of dry months), because the suitability of the agroclimate is the first and most important requirement.

\section{Topography /Landform}

The research area has a variety of landforms that are quite complex in the form of flat, wavy, and small hilly regions. The area includes altitude from $0 \mathrm{~m}$ from sea level (on the marinine plain), to approximately $150 \mathrm{~m}$ above sea level (in the limestone/karst hill complex).

Based on the Geological Map of Bali Island on a scale of 1: 250,000 (Directorate of Geology, 1971), in general the research area consists of 4 landform/ main landform with the following geological formations:

\section{Grup Aluvial}

Physical Condition of South Kuta The alluvial group in the study area is largely Subdistrict

Geography Conditions

The research area is administratively included in the area of Badung Regency. Geographically the area of South Kuta Subdistrict is located at $08^{0} 46^{\prime} 58$ "LS to $115^{0} 10^{\prime} 41.3^{\prime \prime}$ BT. The research area is located at an altitude of 0 - 150 from the sea level a transition area to the marin group, having blocked drainage until it is severely hampered. This group is located in the Kuta district, and South Kuta (Tombolo / Tuban area), Tanjung Benoa, Nusa Dua, and surrounding areas). The parent material is the result of alluvium deposits (sand, gravel and mud)

\section{Marin Group}

The marin group is a recess / sub-resident erosion or deposition area of the process that takes place in the sea water media. In the 
study area, this group was found in the form of beach shoals which spread among others around Seminyak beach, Kuta, Nurah Rai and Nusa Dua.

\section{Karst Grup}

The Karst Group of the study area is a force area with a height difference of less than 300 $\mathrm{m}$. The parent material is suspended from soft limestone and hard. The distribution is mainly especially in the South (Bukit Jimbaran).

\section{Climate}

Based on the Agroklimat zone (Oldeman, et al., 1975) the study area was included in zone D (D3) with an average annual rainfall of $1510 \mathrm{~mm}$ with a dry month of 4-6 months.

\section{Soil}

Based on the Semi-detailed Land Map of Bali the study area consists of several soil orders including: Mollisols, Entisols, Alfisols, Inceptisols (scattered in Bukit Jimbaran area). When paired with the Bali Island Land Map, the Bukit Jimbaran area is included in the association of Mediterranean and Litosols. Entisols are also scattered in the Alluvial group and marin groups around Tuban, along the beaches of Kuta, Nusa Dua, Ngurah Rai. In general, the soil in the study area has a high fertility ability/potential, except for the physical properties of the lithic subgroup Litosol/ Entisol soil type because it is shallow-very shallow soils.

\section{RESULTS AND DISCUSSION}

Based on the results of field observations and the results of analysis of soil samples in the Laboratory are presented in Table 1. While the results of the assessment of the characteristics/quality of the research area and the results of the respective land suitability assessment are presented in Table 1 and Table 2.

The results of the Land Quality/Characteristics Assessment in South Kuta District include: (1) temperature, (2) water availability, (3) root media, (4) nutrient retention, (5) nutrient availability, (6) toxicity, (7) erosion hazard, (8) flood / inundation hazards, (9) land preparation and (10) land management/management.

\section{1) Temperature}

The quality of land temperature determined by the average annual temperature in South Kuta Subdistrict ranges from $25.44-26.26$ oC

1. Quality of water availability

Land quality of water availability is determined by annual average rainfall/ growth period and air humidity, and average dry month/year. Based on the Oldman Agroclimate zone data, the rainfall in the Subdistrict of South Kuta is $1510 \mathrm{~mm}$, the average humidity is 
$79.5 \%$ and the average dry month is $4-6$ months.

\section{2) Availability of water}

The land quality of water availability is determined by the average annual rainfall/growth period and air humidity, and the average dry month/year. Based on data from the Oldman Agro-climate zone, rainfall in South Kuta Subdistrict is 1,735 $\mathrm{mm}$, the average monthly air humidity is $79.5 \%$ and the average dry month is $4-5$ months

3) Rooting media

The quality of rooting media is determined by the characteristics of internal soil drainage / oxygen availability, soil texture, coarse material, and effective depth of soil. Soil drainage / oxygen availability is generally considered good because it is dry land that has never experienced standing water. The characteristics of the soil texture range silty clay loam (SiCL), clay, and clay loam (CL) (slightly smooth to smooth). Characteristics of coarse materials in the soil profile are classified as mild to moderate. The effective depth of the soil is classified as moderate to shallow.

4) Nutrient retention

The quality of soil nutrient retention is determined by cation exchange capacity (CEC), base saturation (BS), soil acidity
$(\mathrm{pH})$, and C-organic. CEC is classified as moderate (16.83 me/100 g) to high (25.96 $\mathrm{me} / 100 \mathrm{~g}) ; \mathrm{KB}$ is classified as high (68.29\%) to very high $(98.70 \%)$, soil $\mathrm{pH}$ is classified as neutral (7.3) to slightly alkaline (8.2); and C-organic ranges from low $(1.11 \%)$ to moderate $(2.52 \%)$.

5) Availability of nutrients

Land quality nutrient availability is determined by N-total soil characteristics, available $\mathrm{P}$, and available $\mathrm{K}$. N-total of the research area is classified as very low $(0.07 \%)$ to low $(0.12 \%)$; P-available is very low $(0.26 \mathrm{ppm})$ to moderate $(22.04$ ppm); and available K Potasium) is high $(329.72 \mathrm{mg} / 100 \mathrm{~g})$ to very high $(678.18$ $\mathrm{mg} / 100 \mathrm{~g})$.

6) Toxicity

The quality of land toxicity determined by soil salinity is very low.

7). Erosion hazard

Land quality erosion hazards are determined by erosion and the level of erosion hazard. The study area is dominated by the shape of the area/flat relief, wavy, wavy, to small hilly with a slope range of $0-3 \% ; 3-8 \% ; 8-15 \% ; 15-$ $30 \%$. Especially in this study sampling was only carried out at a slope of $8-15 \%$ (wavy relief), because above the slope the soil solum was generally very thin and the erosion hazard level was very heavy. Erosion hazard characteristics are 
determined based on the general equation for soil loss (PUKT). Based on these equations the erosion hazard characteristics in the study area are classified as moderate, heavy, to light, dominated by sheet erosion.

8) The flood/inundation hazard

Land quality of flood hazard is determined by the height and duration of inundation. There is no research area that is prone to the danger of flooding and inundation.

9) Quality of land preparation

Land quality of land preparation is determined by the characteristics of rocks on the surface and rock outcrops. Characteristics of surface rocks are classified as moderate to many, and rock outcrops are classified as small to moderate, which is a limiting factor in the development of commodities in the study area.

10. Land management / management

Based on the survey results it is known that in general the ways of managing agricultural land carried out by local farmers are still relatively low, this can be seen from the results of field observations, among others: irregular gardening, poor garden sanitation, lack of additional inputs such as organic materials, fertilization, mulching and lack of maintenance of plants such as pruning.

\section{Actual Land Suitability}

The results of actual and potential land suitability assessments for several evaluated crop commodities are presented in (Table 2). Description of land suitability of each commodity as follows: land suitability evaluation results for several food crop commodities for horticulture fruits (Citrus, Mango, Starfruit, Banana, Sapodilla, Grape, Klengkeng, Papaya, Guava, Guava, Jackfruit, Soursop, Avocado, Srikaya, Breadfruit, and Pineapple) in The sub-district of South Kuta is actually classified as S3 (marginally suitable) to inappropriate $(\mathrm{N})$, with limiting factors: effective depth, land preparation (surface rock, and rock outcrops), erosion hazards, nutrient retention (soil $\mathrm{pH}$ and organic matter), and nutrient availability (especially $\mathrm{N}$ and $\mathrm{P}$ available). 
Table 1. Land Quality/Characteristics of the Research in South Kuta District

\begin{tabular}{|c|c|c|c|c|c|c|c|c|c|c|c|c|c|}
\hline \multirow{2}{*}{$\begin{array}{c}\text { Nu } \\
. \mathrm{Sa} \\
\mathrm{mp} \\
\cdot\end{array}$} & \multirow[t]{2}{*}{ Village } & \multirow[t]{2}{*}{$\begin{array}{l}\text { Subak/ } \\
\text { Dusun }\end{array}$} & \multirow{2}{*}{$\begin{array}{c}\text { Tem } \\
\text { p } \\
(\text { tc }) \\
\left({ }^{\circ} \mathrm{C}\right)\end{array}$} & \multicolumn{2}{|c|}{$\begin{array}{l}\text { water } \\
\text { availability } \\
\qquad \text { (wa) }\end{array}$} & \multicolumn{4}{|c|}{$\begin{array}{l}\text { rooting media } \\
\text { (rc) }\end{array}$} & \multicolumn{4}{|c|}{$\begin{array}{c}\text { nutrient retention } \\
(\mathbf{n r})\end{array}$} \\
\hline & & & & $\begin{array}{c}\text { Rainf } \\
\text { all } \\
(\mathbf{m m})\end{array}$ & $\begin{array}{c}\text { Dry } \\
\text { Mont } \\
\text { h } \\
(\mathbf{d m})\end{array}$ & $\begin{array}{l}\text { Drai } \\
\text { nage }\end{array}$ & $\begin{array}{c}\text { Textu } \\
\text { re }\end{array}$ & $\begin{array}{c}\text { Coars } \\
\text { e } \\
\text { mater } \\
\text { ial } \\
(\%)\end{array}$ & $\begin{array}{c}\text { Efekti } \\
\text { f } \\
\text { Depth } \\
(\text { cm) }\end{array}$ & $\begin{array}{c}\text { CEC } \\
\text { (me/ } \\
\text { 100gr }\end{array}$ & $\begin{array}{l}\text { BS } \\
(\%)\end{array}$ & pH & $\begin{array}{c}\text { C-org } \\
(\%)\end{array}$ \\
\hline 1 & 2 & 3 & 4 & 5 & 6 & 7 & 8 & 9 & 10 & 11 & 12 & 13 & 14 \\
\hline 1 & Pecatu & & $\begin{array}{c}25.5 \\
0\end{array}$ & 1735 & 6 & $\begin{array}{c}\text { Goo } \\
\text { d }\end{array}$ & CL & 5 & $30-75$ & $\begin{array}{c}21.69 \\
(\mathrm{M})\end{array}$ & $\begin{array}{c}93.8 \\
8 \\
(\mathrm{VH} \\
)\end{array}$ & $\begin{array}{l}7.5 \\
(\mathrm{~N})\end{array}$ & $\begin{array}{c}1.51 \\
(\mathrm{~L})\end{array}$ \\
\hline 2 & Pecatu & $\begin{array}{l}\text { Bangk } \\
\text { et } \\
\text { Kangi } \\
n\end{array}$ & $\begin{array}{c}26.2 \\
6\end{array}$ & 1735 & 6 & $\begin{array}{c}\text { Goo } \\
\text { d }\end{array}$ & $\begin{array}{l}\text { SiC } \\
\mathrm{L}\end{array}$ & - & $45-75$ & $\begin{array}{c}24.14 \\
(\mathrm{H})\end{array}$ & $\begin{array}{c}85.1 \\
9 \\
(\mathrm{VH} \\
)\end{array}$ & $\begin{array}{c}7.6 \\
\text { (NA } \\
)\end{array}$ & $\begin{array}{l}1.96 \\
(\mathrm{~L})\end{array}$ \\
\hline 3 & Pecatu & Bingin & $\begin{array}{c}26.2 \\
6\end{array}$ & 1735 & 6 & $\begin{array}{c}\text { Goo } \\
\mathrm{d}\end{array}$ & $\mathrm{C}$ & 3 & $60-75$ & $\begin{array}{c}25.68 \\
(\mathrm{H})\end{array}$ & $\begin{array}{c}86.9 \\
6 \\
(\mathrm{VH} \\
)\end{array}$ & $\begin{array}{c}7.7 \\
\text { (NA } \\
\text { ) }\end{array}$ & $\begin{array}{c}1.11 \\
(\mathrm{~L})\end{array}$ \\
\hline 4 & Pecatu & Kulat & $\begin{array}{c}26.1 \\
5\end{array}$ & 1735 & 6 & $\begin{array}{c}\text { Goo } \\
\mathrm{d}\end{array}$ & SiL & 3 & $50-70$ & $\begin{array}{c}16.83 \\
(\mathrm{M})\end{array}$ & $\begin{array}{c}98.7 \\
0 \\
(\mathrm{VH} \\
)\end{array}$ & $\begin{array}{l}7.4 \\
(\mathrm{~N})\end{array}$ & $\begin{array}{c}1.49 \\
(\mathrm{~L})\end{array}$ \\
\hline 5 & Pecatu & $\begin{array}{l}\text { Girisar } \\
\mathrm{i}\end{array}$ & $\begin{array}{c}26.1 \\
5\end{array}$ & 1735 & 6 & $\begin{array}{c}\text { Goo } \\
\mathrm{d}\end{array}$ & $\mathrm{C}$ & 5 & $30-40$ & $\begin{array}{c}25.96 \\
(\mathrm{H})\end{array}$ & $\begin{array}{c}97.8 \\
5 \\
(\mathrm{VH} \\
)\end{array}$ & $\begin{array}{l}7.5 \\
(\mathrm{~N})\end{array}$ & $\begin{array}{c}1.45 \\
(\mathrm{~L})\end{array}$ \\
\hline 6 & $\begin{array}{c}\text { Jimbaran/ } \\
\text { Cenggilin } \\
\text { g }\end{array}$ & $\begin{array}{l}\text { Tani } \\
\text { Jaya }\end{array}$ & $\begin{array}{c}26.1 \\
2\end{array}$ & 1735 & 6 & $\begin{array}{c}\text { Goo } \\
\mathrm{d}\end{array}$ & $\begin{array}{c}\mathrm{SiC} \\
\mathrm{L}\end{array}$ & - & $60-80$ & $\begin{array}{c}17.96 \\
(\mathrm{M})\end{array}$ & $\begin{array}{c}94.3 \\
8 \\
(\mathrm{VH} \\
)\end{array}$ & $\begin{array}{l}7.3 \\
(\mathrm{~N})\end{array}$ & $\begin{array}{c}1.49 \\
(\mathrm{~L})\end{array}$ \\
\hline 7 & $\begin{array}{l}\text { Jimbaran/ } \\
\text { Cenggilin } \\
\mathrm{g}\end{array}$ & $\begin{array}{l}\text { Tani } \\
\text { Jaya }\end{array}$ & $\begin{array}{c}26.0 \\
6\end{array}$ & 1735 & 6 & $\begin{array}{c}\text { Goo } \\
\mathrm{d}\end{array}$ & $\begin{array}{c}\mathrm{SiC} \\
\mathrm{L}\end{array}$ & - & $30-45$ & $\begin{array}{c}17.85 \\
(\mathrm{M})\end{array}$ & $\begin{array}{c}92.2 \\
5 \\
(\mathrm{VH} \\
)\end{array}$ & $\begin{array}{l}7.4 \\
(\mathrm{~N})\end{array}$ & $\begin{array}{c}1.43 \\
(\mathrm{~L})\end{array}$ \\
\hline 8 & Ungasan & $\begin{array}{l}\text { Eka } \\
\text { Satya } \\
\text { Werdi }\end{array}$ & $\begin{array}{c}25.5 \\
2\end{array}$ & 1735 & 6 & $\begin{array}{c}\text { Goo } \\
\mathrm{d}\end{array}$ & $\mathrm{C}$ & - & $70-80$ & $\begin{array}{c}25.95 \\
(\mathrm{H})\end{array}$ & $\begin{array}{c}68.2 \\
9 \\
(\mathrm{H})\end{array}$ & $\begin{array}{c}8.1 \\
\text { (NA } \\
\text { ) }\end{array}$ & $\begin{array}{l}2.43 \\
(\mathrm{M})\end{array}$ \\
\hline 9 & Ungasan & Langui & $\begin{array}{c}25.4 \\
4\end{array}$ & 1735 & 6 & $\begin{array}{c}\text { Goo } \\
\mathrm{d}\end{array}$ & SiL & 15 & $25-30$ & $\begin{array}{c}16.85 \\
(\mathrm{M})\end{array}$ & $\begin{array}{c}70.1 \\
9 \\
(\mathrm{H})\end{array}$ & $\begin{array}{c}8.2 \\
\text { (NA } \\
\text { ) }\end{array}$ & $\begin{array}{c}1.89 \\
(\mathrm{~L})\end{array}$ \\
\hline 10 & $\begin{array}{l}\text { Ungasan/ } \\
\text { Angas }\end{array}$ & $\begin{array}{l}\text { Angga } \\
\text { sari }\end{array}$ & $\begin{array}{c}25.4 \\
7\end{array}$ & 1735 & 6 & $\begin{array}{c}\text { Goo } \\
\mathrm{d}\end{array}$ & $\mathrm{C}$ & 3 & $60-75$ & $\begin{array}{c}24.75 \\
(\mathrm{~T})\end{array}$ & $\begin{array}{c}69.3 \\
5 \\
(\mathrm{H})\end{array}$ & $\begin{array}{c}8.1 \\
\text { (NA } \\
\text { ) }\end{array}$ & $\begin{array}{l}1.77 \\
(\mathrm{~L})\end{array}$ \\
\hline 11 & Kutuh & $\begin{array}{l}\text { Tulus } \\
\text { Dadi }\end{array}$ & $\begin{array}{c}25.5 \\
8\end{array}$ & 1735 & 6 & $\begin{array}{c}\text { Goo } \\
\mathrm{d}\end{array}$ & $\begin{array}{c}\mathrm{SiC} \\
\mathrm{L}\end{array}$ & 5 & $50-60$ & $\begin{array}{c}18.05 \\
(\mathrm{M})\end{array}$ & $\begin{array}{c}90.1 \\
5 \\
(\mathrm{VH} \\
)\end{array}$ & $\begin{array}{c}7.7 \\
\text { (NA } \\
\text { ) }\end{array}$ & $\begin{array}{l}2.11 \\
(\mathrm{M})\end{array}$ \\
\hline 12 & Kutuh & $\begin{array}{l}\text { Panti } \\
\text { Giri }\end{array}$ & $\begin{array}{c}25.5 \\
9\end{array}$ & 1735 & 6 & $\begin{array}{c}\text { Goo } \\
\mathrm{d}\end{array}$ & $\begin{array}{c}\mathrm{SiC} \\
\mathrm{L}\end{array}$ & 15 & $40-50$ & $\begin{array}{c}17.25 \\
(\mathrm{M})\end{array}$ & $\begin{array}{c}93.6 \\
2 \\
(\mathrm{VH} \\
)\end{array}$ & $\begin{array}{l}7.3 \\
(\mathrm{~N})\end{array}$ & $\begin{array}{l}252 \\
(\mathrm{M})\end{array}$ \\
\hline
\end{tabular}


Table 1. (Continous)

\begin{tabular}{|c|c|c|c|c|c|c|c|c|c|}
\hline \multirow{2}{*}{$\begin{array}{c}\begin{array}{c}\text { Toxisity } \\
\text { (xc) }\end{array} \\
\begin{array}{c}\text { Salinity } \\
\text { (ds/m) }\end{array}\end{array}$} & \multicolumn{3}{|c|}{ Nutrition Avalability (na) } & \multicolumn{2}{|c|}{$\begin{array}{c}\text { Erosion Hazard } \\
(\mathrm{eh})\end{array}$} & \multicolumn{2}{|c|}{$\begin{array}{l}\text { Flood Hazard } \\
(\text { fh) }\end{array}$} & \multicolumn{2}{|c|}{$\begin{array}{l}\text { Land Prepare } \\
\text { (lp) }\end{array}$} \\
\hline & $\begin{array}{c}\text { N-total } \\
(\%)\end{array}$ & $\begin{array}{l}\mathrm{P}_{2} \mathrm{O}_{5} \\
(\mathbf{p p m})\end{array}$ & $\begin{array}{c}\mathrm{K}_{2} \mathrm{O} \\
\mathrm{mg} / 100 \mathrm{gr}\end{array}$ & $\begin{array}{c}\text { Slope } \\
(\%)\end{array}$ & $\begin{array}{l}\text { Erosion } \\
\text { Hazard }\end{array}$ & $\begin{array}{c}\text { Hight } \\
(\mathrm{cm})\end{array}$ & $\begin{array}{l}\text { Long } \\
\text { (hari) }\end{array}$ & $\begin{array}{c}\text { Stoni } \\
\text { ners } \\
(\%)\end{array}$ & $\begin{array}{c}\text { Rock } \\
\text { outcrop } \\
(\%)\end{array}$ \\
\hline 15 & 16 & 17 & 18 & 19 & 20 & 21 & 22 & 23 & 24 \\
\hline $0.06(\mathrm{VL})$ & $\begin{array}{l}0.08 \\
\text { (VL) }\end{array}$ & $7.48(\mathrm{VL})$ & $379.59(\mathrm{H})$ & $8-15$ & $\mathrm{M}-\mathrm{H}$ & - & - & $25-35$ & $23-30$ \\
\hline $0.07(\mathrm{VL})$ & $\begin{array}{l}0.09 \\
\text { (VL) }\end{array}$ & $6.64(\mathrm{VL})$ & $414.64(\mathrm{VH})$ & $0-3$ & M & - & - & 5 & 3 \\
\hline 0.09 (VL) & $\begin{array}{l}0.08 \\
\text { (VL) }\end{array}$ & 0.65 (VL) & $468.09(\mathrm{VH})$ & $3-8$ & M & - & - & $5-10$ & $25-30$ \\
\hline $0.17(\mathrm{VL})$ & $0.12(\mathrm{~L})$ & $22.04(\mathrm{SM})$ & $683.13(\mathrm{VH})$ & $0-3$ & M & - & - & 30 & 20 \\
\hline $0.09(\mathrm{VL})$ & $\begin{array}{l}0.08 \\
\text { (VL) }\end{array}$ & $1.79(\mathrm{VL})$ & $492.83 \mathrm{VH})$ & $8-15$ & M & - & - & 40 & 20 \\
\hline 0.09 (VL) & $0.13(\mathrm{~L})$ & 2.89 (VL) & $465.20(\mathrm{VH})$ & $0-3$ & L-M & - & - & 3 & 3 \\
\hline $0.08(\mathrm{VL})$ & $\begin{array}{l}0.09 \\
\text { (VL) }\end{array}$ & $0.26(\mathrm{VL})$ & $438.12(\mathrm{VH})$ & $3-8$ & L-M & - & - & 15 & 10 \\
\hline 0.11 (VL) & $0.10(\mathrm{~L})$ & 0.63 (VL) & $483.80(\mathrm{VH})$ & $0-3$ & M & - & - & 5 & 10 \\
\hline 0.08 (VL) & $\begin{array}{l}0.08 \\
\text { (VL) }\end{array}$ & $0.26(\mathrm{VL})$ & $678.18(\mathrm{VH})$ & $3-8$ & M & - & - & $60-65$ & 10 \\
\hline 0.09 (VL) & $\begin{array}{l}0.07 \\
(\mathrm{VL})\end{array}$ & 1.16 (VL) & $329.72(\mathrm{H})$ & $0-3$ & L-M & - & - & 25 & 9 \\
\hline 0.11 (VL) & $0.11(\mathrm{~L})$ & 2.86 (VL) & $340.15(\mathrm{H})$ & $3-8$ & $\mathrm{M}$ & - & - & 15 & 5 \\
\hline 0.26 (VL) & $0.12(\mathrm{~L})$ & $6.21(\mathrm{VL})$ & $365.25(\mathrm{H})$ & $8-15$ & $\mathrm{M}-\mathrm{H}$ & - & - & 40 & 15 \\
\hline
\end{tabular}

Notes : $h=$ heavy ; VL = Very Low; L=Low; H=Hight; VH= Very Hight $\mathrm{L}=$ Light ; M=Medium; SiCL=Silty Clay Loam : $\mathrm{C}=$ Clay: $\mathrm{N}=$

Neutral: NA=Not Alcaline

Table 2. Actual and Potential Land Suitability and the Limiting Factors for Each Commodity in the Sub-district of South Kuta

\begin{tabular}{|c|c|c|c|c|c|c|c|}
\hline \multirow[t]{2}{*}{ No } & \multirow{2}{*}{$\begin{array}{l}\text { Commodity/ Number of } \\
\text { observations }\end{array}$} & \multicolumn{6}{|c|}{ Land Suitability } \\
\hline & & Actual & Limiting factor & $\%$ & Potential & Limiting factor & $\%$ \\
\hline 1 & \multicolumn{7}{|l|}{ Pecatu Village (5) } \\
\hline & \multirow[t]{2}{*}{ Orange } & S3 & Lp1.2, eh2, na1.2 & 80 & S2 & wa2, lp2 & 80 \\
\hline & & $\mathrm{N}$ & $\mathrm{rc} 4, \operatorname{lp} 1.2$ & 20 & S3 & $\mathrm{rc} 4, \operatorname{lp} 1.2$ & 20 \\
\hline & \multirow[t]{2}{*}{ Mango } & S3 & Ip1.2, eh2, na1.2 & 80 & S2 & wa2, lp2 & 80 \\
\hline & & $\mathrm{N}$ & $\mathrm{rc} 4, \operatorname{lp} 1.2$ & 20 & S3 & $\mathrm{rc} 4, \operatorname{lp} 1.2$ & 20 \\
\hline & \multirow[t]{2}{*}{ Star fruit } & S3 & Ip1.2, eh2, na1.2 & 80 & S2 & wa2, lp2 & 80 \\
\hline & & $\mathrm{N}$ & $\mathrm{rc} 41, \mathrm{lp} 1.2$ & 20 & S3 & $\mathrm{rc} 4, \operatorname{lp} 1.2$ & 20 \\
\hline & \multirow[t]{2}{*}{ Banana } & S3 & Ip1.2, eh2, na1.2 & 80 & S2 & wa2, lp2 & 80 \\
\hline & & $\mathrm{N}$ & rc4l, lp1.2 & 20 & S3 & $\mathrm{rc} 4, \operatorname{lp} 1.2$ & 20 \\
\hline & \multirow[t]{2}{*}{ Sapodilla } & S3 & Lp1.2, eh2, na1.2 & 80 & S2 & wa2, 1 2 2 & 80 \\
\hline & & $\mathrm{N}$ & $\mathrm{rc} 4, \mathrm{lp} 1.2$ & 20 & S3 & $\mathrm{rc} 4, \mathrm{lp} 1.2$ & 20 \\
\hline & \multirow[t]{2}{*}{ Grape } & S3 & lp1.2, eh2, na1.2 & 80 & S2 & wa2, 1 2 2 & 80 \\
\hline & & $\mathrm{N}$ & $\mathrm{rc} 4, \operatorname{lp} 1.2$ & 20 & S3 & $\mathrm{rc} 4, \mathrm{lp} 1.2$ & 20 \\
\hline & \multirow[t]{2}{*}{ Kelengkeng } & S3 & lp1.2, eh2, na1.2 & 80 & S2 & wa2, 1 2 2 & 80 \\
\hline & & $\mathrm{N}$ & $\mathrm{rc} 4, \mathrm{lp} 1.2$ & 20 & S3 & $\mathrm{rc} 4, \mathrm{lp} 1.2$ & 20 \\
\hline & \multirow[t]{2}{*}{ Pepaya } & S3 & lp1.2, eh2, na1.2 & 80 & S2 & wa2, 1 2 2 & 80 \\
\hline & & $\mathrm{N}$ & $\mathrm{rc} 4, \operatorname{lp} 1.2$ & 20 & S3 & $\mathrm{rc} 4, \operatorname{lp} 1.2$ & 20 \\
\hline & \multirow[t]{2}{*}{ Guava beans } & S3 & lp1.2, eh2, na1.2 & 80 & S2 & wa2, lp2, nr3 & 80 \\
\hline & & $\mathrm{N}$ & $\mathrm{rc} 4, \mathrm{lp} 1.2$ & 20 & S3 & $\mathrm{rc} 4, \mathrm{lp} 1.2$ & 20 \\
\hline & \multirow[t]{2}{*}{ Guava siam } & S3 & lp1.2, eh2, na1.2 & 80 & S2 & wa2, lp2, nr3 & 80 \\
\hline & & $\mathrm{N}$ & $\mathrm{rc} 4, \mathrm{lp} 1.2$ & 20 & S3 & $\mathrm{rc} 4, \mathrm{lp} 1.2$ & 20 \\
\hline & Jackfruit & S3 & lp1.2, eh2, na1.2 & 80 & $\mathrm{~S} 2$ & wa2, lp2, nr3 & 80 \\
\hline
\end{tabular}


INTERNATIONAL JOURNAL OF BIOSCIENCES AND BIOTECHNOLOGY • Vol. 6 No. 2 • April 2019 elSSN: 2655-9994 pISSN: 2303-3371

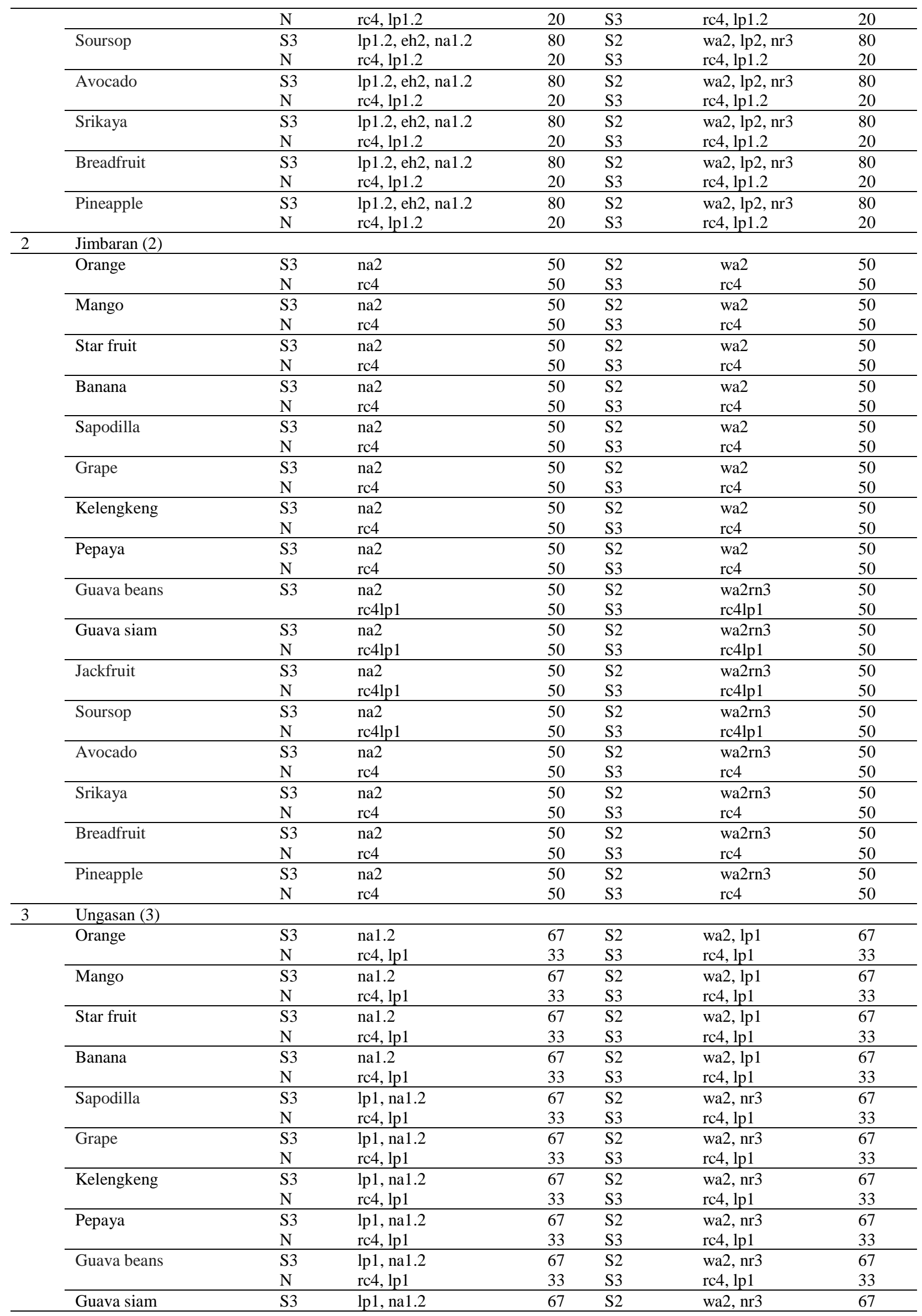




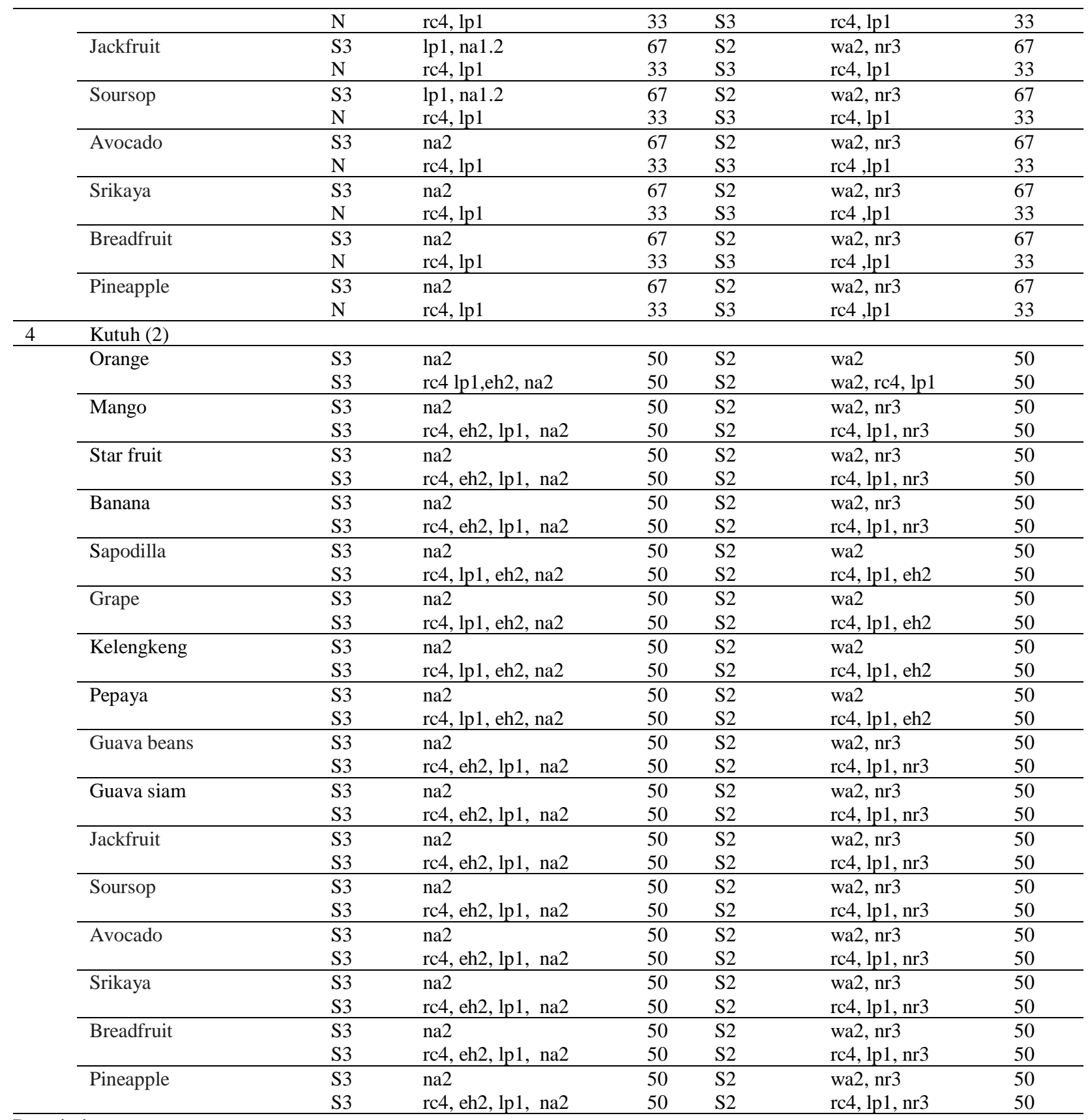

\section{Description:}

S2 = quite suitable; S3 = marginal suitable; $\mathrm{N}=$ non-suitable

wa2 = limiting the long dry moon; rc4 = effective depth of shallow soil; na1 = nutrient delimiter is available at low-very low total $\mathrm{N}$; na2 = low barrier available for P2O5; nr3 = limiting high soil $\mathrm{pH}$; eh2 = erosion hazard barrier; lp1 = limiting rock on the surface; lp 2 = Rock outcrop.
Assuming
some
land limiting water availability (long dry months),

characteristics/qualities that are limiting can be improved, potentially land suitability for the development of fruit horticultural commodities in the South Kuta sub-district which is evaluated is quite suitable (S2) with effective depth of soil, surface rocks and rock outcrops, and nutrient retention (soil $\mathrm{pH}$ is rather high).

Optimization of land use for the development of fruit horticultural 
commodities in the Subdistrict of South Kuta can be done, among others by: making terraces, adding organic matter, adding $\mathrm{N}$ fertilizer (ZA), and adding $\mathrm{P}$ fertilizer (SP36),

\section{Recommendations for Land Development Direction, South Kuta Subdistrict}

The development of agricultural areas in the study area can be linked to tourism development programs is largely determined by physical environmental factors, soil conditions, and the suitability of the land. Based on the results of the research, the research area has good potential for the development of dry land agriculture with annual hotcultural commodities as supporting tourism.

The expansion of agricultural areas for dry land horticultural crops can be directed to flat to choppy areas that have a fairly wide spread. In the surging to hilly areas directed to annual crops (forest wood plants) or agroforestry systems. Forest wood plants suitable for development in the study area (Kuta Selatan sub-district) include: teak, sandalwood, eucalyptus, mahogany, candlenut, and so on. Efforts to develop food crops and horticulture, especially recommended fruits, need to be investigated and tried further by considering the ecological aspects, technical aspects, socio-economic aspects and local culture.

Especially for the technical aspects that are very necessary to do in the development of fruit horticultural commodities in the research area are biophysical specific cultivation technologies that are in accordance with the potential of land suitability, especially in the technology of improving land characteristics/qualities that are limiting factors in its development such as:

1. Limiting the availability of water (dry period) can be overcome by:

a. Mulching technology, both with organic mulch (crop residue/straw) and synthetic mulch (plastic mulch).

b. Increase the holding capacity of the soil to water, namely by adding organic matter.

c. Making biopori holes as lumbng water is planting water during rain and planting water during the dry season.

2. To overcome nutrient retention limitation (a rather high $\mathrm{pH}$ ) for the requirements to grow some plant commodities, it can be done by adding organic matter, adding sulfur-containing fertilizers such as ZA.

3. Limiting the preparation of land, especially the presence of loose rock on the surface can be overcome by temporarily removing from the location of the planting hole.

4. Erosion hazard level limiting can be overcome by making terracing with terrace reinforcement plants with elephant 
grass or setaria grass suitable for so that in turn water will not easily disappear development in the study area.

so that it can be available in a relatively long

5. The low limitation of N-total and P- time for plants. In terms of chemistry organic available nutrient availability can be overcome by adding fertilizer containing $\mathrm{N}(\mathrm{ZA})$ and adding fertilizer containing Pelements such as SP36.

Especially for the addition of organic material is very necessary because $75 \%$ of all the samples analyzed contain relatively low organic matter. Soil texture is classified into a rather smooth to fine group that is dominated by the texture of dusty clay to clay, so that the holding capacity of groundwater is very low so that the soil is dry quickly and dry during the dry season, and very sticky when wet. As it is known that functionalally organic materials can function primarily as soil-based material as well as contain macro and micro nutrients even in low numbers.

According Sisworo (2006) in Pirngadi (2009), that organic matter is a carbon source which is a source of food and energy to live and breed various types of microbes in the soil. Microbia is a very important factor in the decomposition of organic matter in the soil. In addition organic matter also functions in the aggregation process in the formation of soil structures both directly and indirectly. A good soil structure will cause soil aeration to be ideal for the process of air and water circulation, water holding capacity increases, matter is able to provide complete nutrients both macro and micro elements even though the amount is relatively low, so in practice it still has to be balanced with the use of inorganic fertilizers. Dahlan et al. (2008) showed that the treatment of horse manure combined with $\mathrm{N}, \mathrm{P}$, and $\mathrm{K}$ fertilizers significantly affected changes in soil properties, namely moisture content, organic C content, $\mathrm{pH}$, and soil available-P. Increased soil $\mathrm{P}$ levels along with increased moisture content and soil $\mathrm{pH}$, but organic $\mathrm{C}$ levels decreased.

The highest available P-level was obtained in the combination of application of manure application 15 tons ha-1 and NPK fertilizer $300 \mathrm{~kg}$ ha-1 with an incubation period of 14 days. Whereas according to research by Chusnul Agustina (2007) showed that the application of compost at a dose of 30 tons ha-1 had the best effect in improving some soil physical properties, namely being able to reduce soil weight, specific gravity, and rapid drainage pores. In addition it is also able to increase total soil porosity, slow drainage pores and available water pores and aggregate stability. According to Suriadikarta and Simanungkalit (2006), that organic material/fertilizer can act as a primary "binder" to become a secondary grain of soil 
in the formation of a solid aggregate. This situation has a large influence on porosity, storage and water supply, soil aeration, and soil temperature. The role of organic fertilizer indirectly, its effect on soil through the activity of microorganisms, because by providing organic fertilizer will increase the activity of macro-organisms and microorganisms in assisting the process of soil aggregation (as well as the function of organic fertilizers on soil biological properties).

In general, it can be said that soil organic matter is one indicator of soil health because it has several key roles in the soil (providing nutrients for microbial activity, increasing the stability of soil aggregates, and increasing soil recovery power (Sutanto, 2005).

\section{CONCLUSIONS}

The actual land suitability for the development of food crops (corn, soybeans, peanuts, and cassava) in the study area is classified as marginal suitable (S3) with the quality/characteristics of the land as a limiting factor are: effective depth of soil, surface rocks and outcrops rocks, erosion hazards, and nutrient availability, especially N-total and P-available elements. Potentially the land suitability is quite suitable (S2) with the quality/characteristics of the land as a limiting factor are: water availability (long dry months), effective depth of soil, surface rocks and rock outcrops. Suitability of actual land for food crops of horticultural fruits (Oranges, mangoes, starfruit, bananas, sapodilla, grapes, klengkeng, papaya, guava, guava, jackfruit, soursop, avocado, srikaya, breadfruit and pineapple) classified as conditional/marginal suitable (S3), to nonsuitable $(\mathrm{N})$ with land quality/characteristics as limiting factors are: effective depth of soil, surface rock and rock outcrop, erosion hazard, and nutrient availability (especially $\mathrm{N}$-total and P-available elements). Assuming that some of the land quality/characteristics that are inhibiting factors can be improved, the suitability of potential land is quite suitable (S2) to marginal suitable (S3) with the quality/characteristics of the land as a barrier are: water availability (rather long dry months ), effective depth, surface rock and rock outcrop, and rather high soil $\mathrm{pH}$. Increased land productivity in the study area can be done by increasing land management by providing inputs such as: adding organic matter, making biopori holes, mulching (to increase the holding capacity of the soil), adding fertilizer containing $\mathrm{N}$ (ZA), and fertilizer which contains the element Potasium (SP36), performs terracing on sloping lands, rearranging gardens (setting spacing, selecting crop commodities that are in accordance with local biophysical 
conditions), conducting garden sanitation and so on.

Based on direct observations, and the results of soil sample analysis in the study area (specifically in the Subdistrict of South Kuta), the addition of fertilizer containing the element Potasium is highly recommended because in soils with lime parent material in general phosphate fixation is high, making it less available for plants. In addition to the addition of fertilizer containing $\mathrm{N}$ and $\mathrm{P}$ elements, the addition of organic matter is needed. The application of biopori technology to harvest water in the rainy season needs to be tried in the form of demonstration plots.

\section{REFERENCES}

Badung Regency Central Bureau of Statistics. (2015). Badung Dalam Angka. Badung: Badung Regency Central Bureau of Statistics

Dahlan, M., Mulyati and Dulur, N W D. (2008). Study of Application of Organic and Inorganic Fertilizers to Changes in Some Soil Entisol Properties. Agosex Vol. 18 No. 1-3, December 2008 .

Pingardi, K. (2009). The Role of Organic Materials in Increasing Sustainable Rice Production Supports Sustainable Food Security. Agricultural Innovation Development 2 (1), 2009: 48-64.

Regional Regulation (Perda) of Badung Regency No. 26 of 2013 concerning Badung Regency Spatial Planning year 2013-2033.

Ritung, S., Nugroho, K., Mulyani, A., and Suryani, E. (2011). Technical
Guidelines for Land Evaluation for Agricultural Commodities. Jakarta: Research Centers and Development, Agricultural Research and Development Agency, Ministry of Agriculture.

Sutanto, R. (2005). Basics of Soil Science. Concepts and Realities. Yogyakarta: Kanisius Publisher. 